\title{
An Assessment of Ethical Sensitivity of Professional Accountants in Nigeria
}

\author{
Taibat A. Atoyebi ${ }^{1}$, Murtala A. O. Mustafa ${ }^{1} \&$ Moruf A. Mobolaji ${ }^{1}$ \\ ${ }^{1}$ Department of Accounting, Faculty of Management Sciences, University of Abuja, Nigeria \\ Correspondence: Taibat A. Atoyebi, Department of Accounting, Faculty of Management Sciences, University of Abuja, \\ FCT Abuja, Nigeria.
}

Received: February 11, 2018

Accepted: February 26, 2018

Online Published: February 27, 2018

doi:10.11114/bms.v4i1.3019

URL: https://doi.org/10.11114/bms.v4i1.3019

\begin{abstract}
This study assessed the ethical sensitivity of Professional accountants in Nigeria with particular reference to members of The Institute of Chartered Accountants of Nigeria (ICAN) and the Association of National Accountants of Nigeria (ANAN). Professional Commitment, Organizational Commitment, Idealistic and Relativist ethical orientations and their effects on ethical sensitivity of the professional accountants were examined. The descriptive research design was adopted while data were collected through the Accountants' Ethical Sensitivity Scale Questionnaire (AESS) questionnaire administered to 250 professional accountants. Descriptive statistics and regression analysis were used to analyse the collected data. The results revealed that there exists an insignificant negative relationship between professional commitment and professional accountants' ethical sensitivity while idealistic ethical orientation has a significant negative relationship with professional accountants' ethical sensitivity. However, relativist ethical orientations and organizational commitment have a significant positive effect on professional accountants' ethical sensitivity.
\end{abstract}

Keywords: ethics, professional accountant, idealism, relativism, ethical sensitivity

\section{Introduction}

The ethics of a business is a high profile issue owing to sensational corporate scandals that had taken place globally causing extensive damages to the economy. These corporate scandals query the morality of entrepreneurs in general and accountants in particular. Some argued that accountants have been the main contributors to the decline in ethical standards of businesses. A distinguishing feature of the accountancy profession is its acceptance of the responsibility to act in the public interest (IFAC, 2005). Professions that are granted a public trust must confront a wide variety of ethical issues to maintain the confidence of those giving them the trust, accounting is not an exception. In the career of accountants, they come across numerous situations whereby they are tempted to pick between right and wrong. The IESBA's Code of Ethics for Professional Accountants (2013) lay down Integrity; Objectivity; Professional Competence and Due Care; Confidentiality and Professional Behaviour as most essential principles of the ethics of professional accountants. Ethical decision making is a vital part and plays crucial roles in the accounting profession. Several studies in ethical decision making rely on Rest's (1986) model which divides ethical decision process into four (4) independent components of moral action theory: ethical awareness, ethical judgment, ethical intention and ethical behaviour. Ethical awareness for this purpose of this study will be used interchangeably with ethical sensitivity and moral sensitivity. Ethical sensitivity was contrived by Rest (1986) as the top element of his 4 (four) component moral action theory. Overall, ethical sensitivity is the identification of prominent aspects of a situation that involves the "good" and the "bad" of others. Ethical sensitivity is defined as the ability to recognize the ethical nature of a decision (Shaub, Finn \& Munter, 1993). Weaver, Morse and Mitcham (2008) viewed ethical sensitivity as "the capacity to decide with intelligence and compassion, given uncertainty in a care situation...with additional ability to anticipate consequences and courage to act". Bean and Bernadi (2005) argued that shortage of ethical conduct is one of the significant threat to the accounting profession and this threat ought to have more attention. Over the years, arguments are ongoing as to whether ethics can be taught and whether moral education can change the pre-established patterns (Churchill, 1982, Hiltebeitel \& Jones, 1991, Bean \& Bernadi, 2005, Howard, 2007, Mayhew \& Murphy, 2009).

Previous studies in ethics focused mainly on individuals who perceive ethical dimensions or place emphasis on ethical 
values. These studies have not concentrated on persons who do not recognize ethical aspects. A good number of discussions on ethical decision-making framework maintain that ethical perception is the basis for the process of ethical decision making and after that comes ethical reasoning. Recognizing the ethical features of a situation makes dealing with such ethical problem an easy task, for, without the initial recognition, no ethical problem exists. Here in Nigeria, various studies on ethics have delved more on ethical behaviour (Oseni, 2011; Ogbonna \& Appah, 2011; Ogbonna \& Ebimobowei, 2012; Ibietan \& Joshua, 2013; Salaudeen, Ibikunle, \& Chima, 2015), ethical intention and ethical judgements (Fatile, 2013; Gberegbe, Idornigie \& Nkanbia-Davies, 2016; Akenbor \& Tennyson, 2014), Accounting ethics and Professional Accountants (Akadakpo \& Enofe, 2013) and ethical awareness (Okezie, 2016). However, Okezie (2016) delves into the content analysis and so is not an empirical study.

Detecting the level of ethical sensitivity is a crucial step for research into accounting ethical decision making and the accounting profession. The scandals that rock the Enron, WorldCom and Arthur Anderson in the United States and Lever Brothers and Cadbury Plc in Nigeria has put a question mark on the accounting professional ethical conduct, thus defining accountants' ability to detect ethical issues is essential and could help to improve the ethical awareness training. Also, it is imperative to note that high ethical sensitivity does not always translate to more ethical behaviour, it can only describe the existence of an ethical problem but does not ensure that an individual will be averse to behave unethically. The main problem is that some people (including professional accountants) do make wrong decisions, not because they choose to act unethically, but because they cannot identify that particular situation has an element of moral tone (Sidani, Zbib, Rawwas \& Moussawer, 2009). Since solving ethical problems starts with recognition of the ethical aspect of a situation, maybe, we should be more concerned about the person who passes by a moral quandary without recognizing it than we are about the person who consciously and ruthlessly commits a wrong (Hall, 1992). Thus there is need to assess the ethical sensitivity of the professional accountants to be able to address the confidence posed in them by various stakeholders.

\section{Material Studied}

Shaub, Finn and Munter (1993) investigated the relationship between idealism, relativism and ethical sensitivity. They reported a negative relationship between relativism and ethical sensitivity. The outcome is as expected because highly relativistic persons are less likely to accept moral principles, and therefore are less likely to follow a code of ethical conduct. Their results also partly supported Sparks and Hunt (1988) that a negative relationship between ethical sensitivity and idealism. Ameen, Guffey and McMillan, (1996) examined the role gender plays in ethical sensitivity using the socialization approach. Their findings provided evidence that females were significantly more ethically sensitive than males.

Yetmar and Eastman (2000) investigated the impact of role conflict, role ambiguity, job satisfaction, relativism and professional commitment to ethical sensitivity. These factors were mapped into three of the five factors demarcated by Hunt and Vitell (1986): role conflict, job satisfaction, and job ambiguity denoted the organizational environment; relativism was used for personal characteristics; and professional commitment to the professional environment. The results show that role conflict had a negative relationship with ethical sensitivity, while job satisfaction was positively related. Nevertheless, the results show no support for the impact of relativism, professional commitment or role ambiguity on ethical sensitivity.

Chan and Leung (2006) investigated the relationship between ethical reasoning, ethical personality and ethical sensitivity. The personality factors included: ethical orientation (relativism and idealism), the locus of control, age, gender and academic performance. Their findings show no significant relationship between ethical sensitivity and ethical reasoning, but their results support Rest's (1986) theory showing that high moral reasoning does not imply a better recognition of ethical dilemma and a significant relationship between locus of control and ethical sensitivity.

Frisque and Kolb (2008) studied the relationship between the ethics training and attitude and between ethics training and analysis of ethical dilemmas among office professionals. Their results revealed that ethics training improves the ethical sensitivity of office professionals. Bass, Barnett and Brown (1999) examined the impact of ethical ideology on ethical judgment and intention to behave unethically. Their findings showed a significant negative relationship between idealism and ethical judgment, and they deduced that highly idealistic individuals are less likely to ponder on controversial ethical issues.

According to Schlenker and Forsyth (1977), idealism and relativism are factors that can explain a difference in individuals' judgment when faced with a moral issue. They maintained that highly idealistic individuals are those who believe that harm can be prevented by making the correct decision and thus are less likely to identify adverse outcomes that may result from such decisions. They also opined that relativistic individuals are persons who are more likely to reject moral absolutes and believe but would instead use a situation to determine what is ethical. Specifically, those individuals think no code can encompass all cases. 


\subsection{Conceptual Framework and Hypotheses Development}

\subsubsection{Ethical Sensitivity}

Ethical sensitivity is defined as the capacity to recognize the ethical nature of a decision (Shaub, Finn \& Munter, 1993). According to Bebeau, Reifel, and Speidel (1981), moral sensitivity “...is the awareness of how our actions affect other people. It involves being aware of the different possible lines of action and how each line of action could affect the parties involve (including oneself)". Moral sensitivity is necessary to become aware that a moral issue is involved in a situation. Fahimeh and Mahdi (2013) considered ethical sensitivity as the ability to recognize the ethical nature of a position in a professional context. Accordingly, Weaver, Morse, and Mitcham (2008) viewed ethical sensitivity as the capacity to decide with intelligence and compassion, given the uncertainty in a care situation with additional ability to anticipate consequences and at the same time have the courage to act.

\subsubsection{Professional Commitment}

Professional Commitment is defined as the intensity of an individual's identification with, and level of involvement in a profession (Mowday, Porter, \& Steers, 1982). The identification requires some degree of conformity with the goals and values of the profession, including both moral and ethical values. Commitment is described in the literature (Aranya, Pollock \& Amernic, 1981; Aranya \& Ferris, 1984; Harrell, Chewning \& Taylor, 1986) using three dimensions. It consists of: (i) A confidence in and acceptance of goals and values of the profession; (ii) willingness to exert considerable effort on behalf of the profession and (iii) the desire to maintain membership in the profession. Professional Commitment was developed during the socialization process that accompanies entry into the profession, the majority of which takes place in school during the early years of the professional accountants' career. This study, therefore, developed a testable hypothesis from prior studies.

$\mathrm{H}_{01}$ : There is no significant relationship between professional commitment of an Accountant and his or her level of ethical sensitivity

\subsubsection{Relativism / Relativistic Ethical Orientation}

Relativism describes to what extent individuals are likely to accept or reject moral absolutes (Forsyth, 1980). Highly relativistic individuals are likely to depend on moral absolutes. They do not pay much attention to any set of rules for ethical conduct since they do not accept their applicability. Therefore, they will restrict their knowledge and usage of the rules. Previous studies have revealed that highly relativistic individuals' scores low in ethical awareness (Shaub, Finn \& Munter 1993; Sparks \& Hunt, 1998). Shaub, Finn and Munter (1993) investigated the relationship between idealism, relativism and ethical sensitivity. Their results revealed a negative relationship between relativism and ethical sensitivity. These results have led to the development of the testable hypothesis.

$\mathrm{H}_{02}$ : Professional accountant's relativistic ethical orientation does not have a significant effect on his or her level of ethical sensitivity

\subsubsection{Idealism / Idealistic Ethical Orientation}

Idealism means complying with universal moral rules to act rightly and avoid harming others. Highly idealistic individuals are those who believe that harm can be avoided by making the correct decision and therefore are less likely to recognize negative outcomes that may result from such decisions. Shaub, Finn and Munter (1993) revealed a negative relationship between ethical sensitivity and idealism from their study of the relationship between idealism, relativism and ethical sensitivity. Douglas and Wier (2000) maintained that more idealistic managers are less likely to act unethically. Highly idealistic individuals are concerned about the harm associated with an action, and they will spend more efforts assessing an ethical dilemma to avoid any possible injury to others. The relevant hypothesis derived from this discussion is:

$\mathrm{H}_{03}$ : Professional accountant's Idealistic ethical orientation does not have a significant effect on his or her level of ethical sensitivity.

\subsubsection{Organizational Commitment}

Specifically, organizational commitment consists of 1 . A belief in and acceptance of the goals and values of the organization. 2. Willingness to exert considerable effort on behalf of the organization. 3. A desire to maintain membership in the organization (Harrell, Chewning \& Taylor, 1986). The goals and values of the organization differ depending on the nature of the organization. Historically, researchers have assumed, based on the results of early research into the constructs, that people are usually not high in both professional and organizational commitment. The study of Sorensen and Sorensen, (1974) supports the existence of a conflict between commitment to the organization and the level of ethical sensitivity. An employee would perhaps choose to be less sensitive to situations having ethical content to be loyal to an organization whose goals differed from those of his or her profession. However, an employee 
that was loyal to an organization that communicated strong support from top management for ethical behaviour would perhaps be more sensitive to ethical issues, so as not to hurt the reputation of the firm or fall short of the management expectations. Thereby, this would be inconsistent with goal congruence between the professional organizations and professionals as demonstrated in the findings of Aranya \& Ferris (1984) and Lachman \& Aranya (1986). Accountants that are highly committed to their organization and profession would, therefore, be expected to exhibit ethical sensitivity in situations that have an impact on the organization. Despite the fact that a specific direction is hypothesized for this relationship, strong arguments can be made for either negative or positive relationship. A review of prior studies has resulted in the development of a testable hypothesis.

$\mathrm{H}_{04}$ : There is no significant relationship between the level of organizational Commitment of Professional Accountants and his or her level of ethical sensitivity.

\section{Area Description}

The study adopted descriptive survey design. The target population of this study comprised of Nigerian professional accountants in the public and private sectors, who are either teaching or non -teaching members of ANAN and ICAN. Data were collected using Accountants' Ethical Sensitivity Scale Questionnaire (AESS); Professional Commitment Questionnaire; Organization Commitment Questionnaire; Idealism Questionnaire and Relativism Questionnaire from a target population of 650 during some of the professional programmes like the MCPE / MCPD and other professional activities that attracts the presence of majority of the professionals in Lagos and Abuja. The questionnaires were administered to a random sample of 250 respondents, but only 210 of them were returned. The instrument used was Accountants Ethical Sensitivity Scale. The questionnaire consisted of demographic variables in Section A; Section B was 18 items adapted from AESS by Triki (2011). Section C contained 15 items Professional Commitment scale adapted from Aranya, Pollock, \& Amernic (1981); Section D consists of 15 items Organizational Commitment Scale adapted from Aranya \& Ferris (1984), while Sections E and F contains 10 items adapted from Forsyth (1980) for Ethical positions of Idealism and Relativism respectively.

\section{Methods}

The respondents were asked to rate the severity of these items in the context of accounting ethics. All items of scale were measured by using a seven-point Likert-type scale ranging from 1=strongly unethical,2= moderately unethical, 3=Slightly unethical, 4= Neutral, 5=Slightly ethical, 6=Moderately ethical and 7=Strongly Ethical. Means of the ethical sensitivity scale items are ranging from 1to7. For each item, average scores (Mean) are calculated in order to analyse the data.

Regression analysis was used to test for the independent variable internal consistency and validity of the hypotheses while Descriptive statistics are used to report the demographics of the final samples. The study employed the Statistical Package for Social Sciences (SPSS) version 20 and STATA 13 to analyze statistical dependencies between the indicators, and parametric Cronbach alpha measure will estimate how well the items cooperate with each dimension, the coefficients were calculated for each dimension. This is because the single -item questions pertaining to a construct are not always reliable and should not be used in drawing conclusions. Factor Analysis was used to reduce the 42 items in the original questionnaire for dependent variables (Ethical sensitivity) to 18 items which are then categorized into six dimensions recognized in the daily dealings of a professional accountant. The first stage of the analysis describes the psychometric properties of the dimensions of AESS. The statistical software program can analyse the data easily without memorizing or using statistical formulas.

\subsection{Model Specification}

To provide support for the instrument's content validity, the below-shown model is used:

$$
\mathrm{AESM}=\beta_{0}+\beta_{1} \text { ORGCOM }_{\mathrm{i}}+\beta_{2} \text { PROFCOM }_{\mathrm{i}}+\beta_{3} \text { RELCOM }_{\mathrm{i}}+\beta_{4} \mathrm{IDECOM}_{\mathrm{i}}+\varepsilon_{\mathrm{i}}
$$

Where:

$$
\begin{aligned}
& \text { AESS=Accountants Ethical Sensitivity Model } \\
& \beta 0=\text { The Constant } \\
& \text { ORGCOM } M_{i}=\text { Organizational Commitment component } \\
& \text { PROFCOM }=\text { Professional Commitment component } \\
& \text { RELCOM }=\text { Relativism component } \\
& \text { IDECOM }=\text { Idealism component } \\
& \text { B1- } \beta 4=\text { Regression co efficient of the variables }
\end{aligned}
$$


$\varepsilon_{i}=$ Error term

\section{Results}

5.1 Descriptive Statistics

Table 1. Descriptive Statistics of the Variables

\begin{tabular}{lllllll}
\hline & No & Min & Max & Mean & Std. Deviation & Skewness \\
\hline AESS & 210 & 1.17 & 2.33 & 1.7296 & .31578 & -.055 \\
PROFCOM & 210 & 4.53 & 5.67 & 5.0375 & .17424 & -.123 \\
ORGCOM & 210 & 3.80 & 4.67 & 4.1949 & .11890 & -.364 \\
IDECOM & 210 & 5.60 & 6.50 & 6.2752 & .16589 & -1.409 \\
RELCOM & 210 & 3.60 & 4.50 & 3.9948 & .16921 & .340 \\
\hline
\end{tabular}

Source: STATA 13 output, 2017

AESS = Accountants Ethical Sensitivity Scale; PROFCOM = Professional Commitment $;$ ORGCOM = Organizational Commitment; IDECOM = Idealism Scale; RELCOM = Relativism Scale

As shown in Table 1, the mean value of respondents to the Accountants Ethical Sensitivity Scale was 1.7296 and standard deviation of 0.31578 . This shows that there is a wide variation in the ethical sensitivity across the sample, which means most of the accountants are highly sensitive to the situations having ethical contents in their various professional endeavours. The mean value of the professional commitment is 5.0375 , which means that the professional commitment of the respondents was high because the minimum value is 4.53 and the maximum is 5.67 . Besides, there is a difference between the responses at the standard deviation of $17.42 \%$. The mean of organizational commitment is 4.1949 , which means that the organizational commitment of the respondents was equally high because the minimum value is 3.8 and the maximum value is 4.67 . Although, not as high as the professional commitment, at $11.89 \%$ standard deviation.

The mean value of the Idealistic ethical orientation is 6.2752 , which indicates that most of the respondents are idealistic in orientation with the maximum value of 6.5 and a minimum value of 5.6.The mean value of the Relativist ethical orientation of the respondent was 3.9948, which shows that some of the respondents chose to be a relativist in their ethical orientation with a maximum value of 4.5 and a minimum value of 3.6. This then meant that, although the code of ethics could influence the accountants' ethical orientation, the experience and individual nature and dispositions may not be totally ruled out. Above all the Idealistic ethical orientation gained more ground than the Relativist ethical orientation in the sample of respondents.

\subsection{Test for Multicollinearity}

Before running the regression analysis, there was the need to verify the correlation between the variables in the model. Multicolinearity can be assessed through correlation matrix and through variation inflation factor (VIF). Table 2 shows the result of the Spearman's Rho correlation indices for all the variables.

Table 2. Spearman's rho Correlations

\begin{tabular}{lllllll}
\hline & & AESS & PROFCOM & ORGCOM & IDECOM & RELCOM \\
\hline AESS & Pearson Correlation & 1 & $-.205^{* *}$ & .037 & $-.226^{* *}$ & $.222^{* *}$ \\
& Sig. (2-tailed) & & .003 & .590 & .001 & .001 \\
& $\mathrm{~N}$ & 210 & 210 & 210 & 210 & 210 \\
PROFCOM & Pearson Correlation & $-.205^{* *}$ & 1 & $.135^{*}$ & $.342^{* *}$ & $-.232^{* *}$ \\
& Sig. (2-tailed) & .003 & & .050 & .000 & .001 \\
& $\mathrm{~N}$ & 210 & 210 & 210 & 210 & 210 \\
ORGCOM & Pearson Correlation & .037 & $.135^{*}$ & 1 & $.403^{* *}$ & .078 \\
& Sig. (2-tailed) & .590 & .050 & & .000 & .261 \\
& $\mathrm{~N}$ & 210 & 210 & 210 & 210 & 210 \\
IDECOM & Pearson Correlation & $-.226^{* *}$ & $.342^{* *}$ & $.403^{* *}$ & 1 & $-.179^{* *}$ \\
& Sig. (2-tailed) & .001 & .000 & .000 & & .010 \\
& $\mathrm{~N}$ & 210 & 210 & 210 & 210 & 210 \\
RELCOM & Pearson Correlation & $.222^{* *}$ & $-.232^{* *}$ & .078 & $-.179^{* *}$ & 1 \\
& Sig. (2-tailed) & .001 & .001 & .261 & .010 & \\
& $\mathrm{~N}$ & 210 & 210 & 210 & 210 & 210 \\
\hline
\end{tabular}

Source: STATA 13 output, 2017

\footnotetext{
**.Correlation is significant at the 0.01 level (2-tailed).

*. Correlation is significant at the 0.05 level (2-tailed).
} 
The correlation analysis shows that Accountants' ethical sensitivity has a significant negative relationship with Professional commitment at $10 \%$ significant level $(\mathrm{p}=0.003)$; Idealistic ethical orientation also has significant negative relationship with Accountants' ethical sensitivity at $1 \%$ significant level $(p=0.001)$, whilst Relativistic ethical orientation also has a significant positive relationship with Accountants ethical sensitivity at $10 \%$ significant level $(\mathrm{p}=0.001)$. The Organizational commitment has no relationship with Accountants' ethical sensitivity on the side of the dependent variable and the predictor variables.

Within the predictor variables, the Professional commitment has a significant positive relationship with Organizational commitment at 5\% level $(\mathrm{p}=0.050)$; Idealistic ethical orientation at $1 \%(\mathrm{p}=0.000)$ and Relativist ethical orientation at $1 \%$ significant level $(\mathrm{p}=0.001)$ respectively. The Idealistic ethical orientation also has a significant negative relationship with the Relativist ethical orientation at $1 \%$ significant level $(\mathrm{p}=0.010)$. This result indicates the need to pay attention to possible multi-co linearity problem in the regression analysis. Table 3 shows the variation inflation factor (VIF)

Table 3. Results of the Variance Inflation Factor Test

\begin{tabular}{lll}
\hline Variable & VIF & 1/VIF \\
\hline IDECOM & 1.36 & 0.732824 \\
ORGCOM & 1.23 & 0.813912 \\
PROFCOM & 1.17 & 0.851775 \\
RELCOM & 1.10 & 0.908264 \\
Mean VIF & 1.22 & \\
\hline
\end{tabular}

Source: STATA 13 output, 2017

As a rule of thumb, a Variable Inflation factor in excess of 5 is considered an indication of harmful multicollinearity. All the VIF are less than 5 and average VIF is 1.22, as show in (Table 3) therefore, it can be said that there is no problem of multicollinearity problem for the model. The results of the regression analysis can, therefore, be interpreted with a greater degree of confidence.

\subsection{Normality Test}

The results of normality test is as shown in Table 4.

Table 4. Normality Result

\begin{tabular}{llllll}
\hline Variables & Obs & $\mathrm{W}$ & $\mathrm{V}$ & $\mathrm{Z}$ & Prob $>\mathrm{Z}$ \\
\hline AES & 210 & 0.98271 & 2.692 & 2.284 & 0.01118 \\
PROFCOM & 210 & 0.98851 & 1.789 & 1.341 & 0.08989 \\
ORGCOM & 210 & 0.96958 & 4.735 & 3.587 & 0.00017 \\
IDECOM & 210 & 0.90856 & 14.234 & 6.125 & 0.00000 \\
RELCOM & 210 & 0.99121 & 1.368 & 0.723 & 0.23493 \\
\hline
\end{tabular}

Source: STATA 13 output, 2017

The variables of the study were subjected to Shapiro-Wilk (W) for data normality; the technique tests the null hypothesis (that the data is normal), that is the variables came from a normally distributed population. Table 4 indicates that the data for all the variables are normally distributed.

\subsection{Regression Results}

Table 5. Result of Regression Analysis

\begin{tabular}{ll}
\hline Summary of the Result & \\
No of observation & 210 \\
F. Statistic & $6.25^{* * *}$ \\
R. squared & 0.1086 \\
Adj. R- squared & 0.0913 \\
\hline
\end{tabular}

Source: STATA 13 output, 2017

The goodness of fit test as shown in Table 5 reveals an adjusted $\mathrm{R}^{2}$ of .091 indicating $9.1 \%$ of the variance in the dependent variable are explained by independent variables. Thus the model has a fair explanatory power. The $\mathrm{F}$ statistics is significant at 1 percent. 
Table 6. Regression Result

\begin{tabular}{lllllll}
\hline Variables & Coef. & Std. Err & $\mathrm{t}$ & $\mathrm{p}>|\mathrm{t}|$ & $95 \%$ Conf. & Interval \\
\hline PROFCOM & -.2092016 & .1294827 & -1.62 & 0.108 & -.4644901 & .0460869 \\
ORGCOM & .3359383 & .194117 & 1.73 & 0.085 & -.0467836 & .7186601 \\
IDECOM & -.401634 & .1466291 & -2.74 & 0.007 & -.6907284 & -.1125396 \\
RELCOM & .2748057 & .129119 & 2.13 & 0.035 & .0202342 & .5293772 \\
Const & 2.796805 & 1.175117 & 2.38 & 0.018 & .4799413 & 5.11367 \\
\hline
\end{tabular}

Source: STATA 13 output, 2017

\section{Discussion}

Table 6 shows that there is a negative insignificant relationship between ethical sensitivity and professional commitment at a negative coefficient value of -0.2092016 ( $p$-value 0.108 ) and standard error of 0.1295 . This means that professional commitment may not directly predict ethical sensitivity of an accountant. Hence $\mathrm{H}_{\mathrm{ol}}$ is not rejected.

However, for the relationship between relativistic ethical orientation and ethical sensitivity, the result in Table 6 shows that there is a significant positive relationship at $5 \%$ significant level between the relativistic ethical orientation and ethical sensitivity of Accountants at a coefficient of 0.2748057 (p-value 0.035 ). This then means that relativistic ethical orientation may directly predict the level of ethical sensitivity of an accountant. Therefore the null hypothesis of $\mathrm{H}_{\mathrm{o} 2}$ is rejected and alternative hypothesis: Professional accountant's relativistic ethical orientation does have a significant effect on his or her level of ethical sensitivity

In term of the relationship between the idealistic ethical orientation and ethical sensitivity, the results showed that there is a significant negative relationship at $1 \%$ level of significance with a co -efficient -.401634 (p-value 0.007). This indicated that there is a high negative relationship between the idealistic ethical orientation and ethical sensitivity of an accountant; this means that the idealistic ethical orientation can directly predict the level of ethical sensitivity of an accountant. Therefore the null hypothesis $\mathrm{H}_{03}$ is rejected. Lastly, the results in Table 6 also shows that there is a significant positive relationship at $10 \%$ level of significance between organizational commitment and ethical sensitivity, (p-value 0.085 ) and coefficient of 0.4028 . This means that organizational commitment and ethical sensitivity are positively correlated. Therefore the null hypothesis $\mathrm{H}_{04}$ is not accepted. Thus, the alternate hypothesis is accepted, that there is significant relationship between level of organizational Commitment of Professional Accountants and his or her level of ethical sensitivity.

\section{Conclusion}

Each step of the ethical decision-making process is independent and does not follow each other consequentially to an ethical behaviour. However, the detection of an ethical dilemma will assist to be conscious and perhaps move to the next step in the ethical decision process. The measure of accountants' ethical sensitivity, though preliminary in nature, was found to be realistic by the respondents. The results in this study indicated a negative insignificant relationship between professional commitments and Accountants Ethical Sensitivity. The finding is consistent with the findings of Yetmar and Eastman, (2000); and Shaub, Finn and Munter, (1993). The findings of this study also showed that relativistic ethical orientation has a significant positive relationship with Accountants Ethical Sensitivity. This means that as the relativism tendency increases, the Accountants' ethical sensitivity also increase, which implies that relativistic ethical orientation will directly predict the level of ethical sensitivity of an accountant. The finding is consistent with Shaub (1989), Douglas and Weir (2000). However, the findings contradict Shaub, Finn, and Munter (1993), and Chang and Leung (2006).

There is a significant negative relationship between the idealistic ethical orientation and ethical sensitivity of an accountant based on correlation and regression analysis results. This means that as idealistic ethical orientation increases ethical sensitivity of an accountant decreases which implies that idealistic ethical orientation can predict the level of ethical sensitivity of an accountant. This finding is inconsistent with Yetmar and Eastman (2000). However, it is consistent with Aranya and Ferris (1984). Organizational commitment has a significant relationship with Accountants' ethical sensitivity. This means that for any increase in organizational commitment will lead to an increases in Accountants' Ethical Sensitivity. This finding is consistent with findings of Aranya and Ferris (1984), and Sparks and Hunt (1998).

The study is potentially helpful in that it gives practitioners direction in developing ethics courses by providing evidence regarding what constructs affect ethical sensitivity as well as the effects of ethical orientations on Professional Commitment and Organizational commitment. The study has revealed the need for professional accountants to place greater emphasis on ethical sensitivity and the employers evaluate the accountants' ethical orientation so as to maximise output from the employee. 


\section{References}

Akadakpo, B. A., \& Izedonmi, F. I. O. (2013). Ethical practices of the professional accountant in Nigeria. Research Journal of Finance and Accounting 4(7), 59-66.

Akenbor, C. O., \& Tennyson, O. (2014). Ethics of accounting profession in Nigeria. Journal of Business and Economic, 5(8), 1374-1382.

Ameen, E. C., Guffey, D. M., \& McMillan, J .J. (1996). Gender differences in determining the ethical sensitivity of future accounting professionals. Journal of Business Ethics, 15(5), 591-597. https://doi.org/10.1007/BF00381934

Aranya, N., \& Ferris, K. R. (1984). A re-examination of accountants' organizational- professional conflict. The Accounting Review, 59, 1-15.

Aranya, N. R., Pollock, J., \& Amernic, J. (1981). An examination of professional commitment in public accounting. Accounting organizations and society, 6, 271-280. https://doi.org/10.1016/0361-3682(81)90007-6

Bass, K., Barnett, T., \& Brown, G. (1999). Individual difference variables, ethical judgments, and ethical behaviour intentions, Business Ethics Quarterly, 9(2), 183-205. https://doi.org/10.2307/3857471

Bean, D., \& Bernadi, R. (2005). Accounting ethics courses: A professional necessity. The CPA Journal, 75(12), 64-65.

Bebeau, M. J., Reifel, N. M., \& Speidel, T. M. (1981). Measuring the type and frequency of professional dilemmas in dentistry. Program and abstracts, abstract no 89. Journal of Dental Research, 60.

Chan, S. Y. S., \& Leung, P. (2006). The effects of accounting students' ethical reasoning and personal factors on their ethical sensitivity. Managerial Auditing Journal, 21(4), 436. https://doi.org/10.1108/02686900610661432

Churchill, L. (1982). The teaching of ethics and moral values in teaching. Some contemporary Confusion. Journal of Higher Education. 53(3), 296-306. https://doi.org/10.1080/00221546.1982.11780455

Douglas, P. C., \& Weir, B. (2000). Integrating ethical dimensions into a model of budgetary slack creation. Journal of Business Ethics, 28(3), 267-277. https://doi.org/10.1023/A:1006241902011

Fahimeh, S., \& Mahdi, M. (2013). Factors influencing auditor's ethical sensitivity in ethical decision making: evidence from Iran. Universal Journal of Management and Social Sciences, 3(11).

Fatile, J. O. (2013). Ethics and performance in the Nigerian public sector. International Journal of Advanced Research in Management and Social Sciences, 2(10), 132-150.

Forsyth, D. R. (1980). A taxonomy of ethical ideologies. Journal of Personality and Social Psychology, 39, 175-184. https://doi.org/10.1037/0022-3514.39.1.175

Frisque, D. A., \& Kolb, J. A. (2008). The effects of an ethics training program on attitude, knowledge, and transfer of training of office professionals: a treatment-and control-group design. Human Resource Development Quarterly, 19(1), 35-53. https://doi.org/10.1002/hrdq.1224

Gberegbe, F. E., Idornigie, G. A., \& Nkanbia, D. L. O. (2016). Does Professional code of ethics influence professional accounting practice in Rivers state, Nigeria? Journal of Research in Business and Management, 4(1), 14-21.

Hall, W. D. (1992). Ethical Issues in the practice of Accounting. In W. S. Albrecht (Eds.). Ethical issues in the practice of accounting, 31- 43. Cincinnati, Ohio: South-Western Publishing Co.

Harrell, A., Chewning, E., \& Taylor, M. (1986). Organizational-professional conflict and the job satisfaction and turnover intentions of internal auditors. A Journal of Practice \& Theory, 5, 109-121.

Hiltebeitel, K., \& Jones, S. (1991). Initial evidence on the impact of integrating ethics into accounting education. Issues in Accounting Education, 6(2), 262-275.

Howard, J. (2007). Ethics cannot be taught. The CPA Journal, 77(4), 15-22.

Hunt, S. D., \& Vitell, S. (1986). A general theory of marketing ethics. Journal of Macro marketing, 8, 5-16. https://doi.org/10.1177/027614678600600103

Ibietan, J., \& Joshua, S. (2013). Ethics in the Nigerian public sector: A discourse. The Public Administration and Social Policies Review, 1(10), 46-59.

IESBA. (2013). Code of ethics for professional accountants. Retrieved June 20, 2017 from www.IESBA.org

IFAC. (2005). Code of Ethics for Professional Accountants. Retrieved June 20, 2017 from www.ifac.org

Lachman, R., \& Aranya, N. (1986). Evaluation of alternative models of commitments and job attitudes of professionals. Journal of Occupational Behaviour, 7, 227-243. https://doi.org/10.1002/job.4030070307 
Mayhew, B., \& Murphy, P. (2009). The impact of ethics education on reporting behaviour. Journal of Business Ethics, 86(3), 397-416. https://doi.org/10.1007/s10551-008-9854-5

Mowday, R. T., Porter, L. W., \& Steers, R. M. (1982). Employees-organization linkages. New York: Academic Press.

Ogbonna, G. N., \& Appah, E. (2011). Ethical compliance by the accountants on the quality of financial reporting and performance of quoted companies in Nigeria. Asian Journal of Business Management, 3(3), 152-160.

Ogbonna, G. N., \& Ebimobowei, A. (2012). Effect of ethical accounting standards on the quality of financial reporting and performance of quoted companies in Nigeria. Asian Journal of Business and Management, 3(3), 152-160.

Okezie, S. O. (2016). Auditing and ethical sensitivity: Resolving the dilemma. European Journal of Accounting, Auditing, and Finance Research. 4(4), 25-36.

Oseni, A. I. (2011). Unethical behaviour by professional in an organization. Research Journal of Finance and Accounting, 2(2), 1-8.

Rest, J. R. (1986). Moral development: Advances in research and theory. New York: Praeger.

Salaudeen, Y. M., Ibikunle, J., \& Chima, I. B. (2015). Unethical accounting practice and financial reporting quality: Evidence from Nigeria. International Journal of Academic Research in Accounting, Finance, and Management Sciences, 5(2), 143-150. https://doi.org/10.6007/IJARAFMS/v5-i2/1689

Schlenker, B. R., \& Forsyth, D. R. (1977). On the ethics of psychological research. Journal of Experimental Social Psychology, 13(4), 369-396. https://doi.org/10.1016/0022-1031(77)90006-3

Shaub, M. K., Finn, D. W., \& Munter, P. (1993). The effects of auditors' ethical orientation commitment and ethical sensitivity. Behavioural Research in Accounting, 5(1), 145-169.

Sidani, Y., Zbib, I., Rawwas, M., \& Moussawer, T. (2009). Gender, age, and ethical sensitivity: the case of Lebanese workers. Gender in Management: An International Journal 24(3), 211-227. https://doi.org/10.1108/17542410910950886

Sorensen, J. F., \& Sorensen, T. C. (1974). The conflict of professionals in bureaucratic organizations. Administrative Science Quarterly, 3, 98-106. https://doi.org/10.2307/2391790

Sparks, J. R., \& Hunt, S. D. (1998). Marketing researcher ethical sensitivity: Conceptualization, measurement, and exploratory investigation. The Journal of Marketing, 62(2), 92-109. https://doi.org/10.2307/1252163

Triki, A. (2011). Accountants' ethical sensitivity. Unpublished master's dissertation, Brock University, St. Catharine, Ontario. Canada.

Weaver, K., Morse, J., \& Mitcham, C. (2008). Ethical sensitivity in professional practice: Concept analysis. Journal of Advanced Nursing, 62(5), 607-618. https://doi.org/10.1111/j.1365-2648.2008.04625.x

Yetmar, S. A., \& Eastman, K. K. (2000). Tax practitioners' ethical sensitivity: A model and empirical examination. Journal of Business Ethics, 26(4), 271-288. https://doi.org/10.1023/A:1006294517573

\section{Copyrights}

Copyright for this article is retained by the author(s), with first publication rights granted to the journal.

This is an open-access article distributed under the terms and conditions of the Creative Commons Attribution license which permits unrestricted use, distribution, and reproduction in any medium, provided the original work is properly cited. 